\title{
Juridical Analysis of Protection of Bank Customers from Skimming Action Reviewed from Consumer Protection Law
}

\author{
Nor Hazrina; Yulfasni; Delfianti \\ Faculty of Law, University of Andalas Padang, Indonesia
}

http://dx.doi.org/10.18415/ijmmu.v6i4.1051

\begin{abstract}
Today technology is growing rapidly including in the banking sector, banks as service providers continue to provide services to facilitate customer transactions, one of which is in the form of an ATM machine (Automatic Teller Machine), besides that customers as consumers in banking services also have the right to get comfort and security for funds entrusted by the customer to the bank, and also the bank is obliged to provide protection and safeguard against crime by third parties with skimming mode, as stipulated in the consumer protection law. The method in this research is normative juridical research. Research data were collected through literature study and interviews with resource persons to obtain primary data and literature studies to obtain primary data. The focus of this research is to find out how the Protection of Bank Customers From the Act of Skimming Viewed from the Consumer Protection Regulation. The results of the study indicate that the form of legal protection for bank customers from acts of skimming in terms of the Consumer protection Act that is legal protection and direct protection, and if there is a skimming action that is detrimental to the customer, and it is proven that there is no element of negligence from the customer, the bank will provide compensation for the amount of money lost.
\end{abstract}

Keywords: Protection; Bank Customers; Skimming; Consumer Protection Law

\section{Introduction}

Banks which are one of the financial institutions have a role in helping the economic development of a country. The growth of a good and healthy bank development will encourage the people's economy to increase, on the contrary, the development of a bank experiencing a crisis can be interpreted as a country's economic conditions in decline. As mentioned in article 1 paragraph (2) in Law No.10/1998 concerning Banking regarding definition of a bank:

A bank is a business entity that collects funds from the public in the form of deposits and distributes them to the community in order to improve the lives of many people. ${ }^{1}$

\footnotetext{
${ }^{1}$ Sentosa Sembiring, Association of Banking and Deposit Insurance Corporation, Bandung, Nuansa Aulia, 2005, page 13
} 
In terms of advancing the banking business, of course it is inseparable from the role of customers as consumers of bank products and services. This relationship is very good and mutually beneficial between the bank and the customer, thus the more customers who trust the bank, the more funds can be collected from the public.

In Indonesia it also has a mission, and a special function related to banking institutions that can be directed as an agent of development, namely as an institution that aims to support the implementation of national development in order to improve equitable development and its results, economic growth and stability national direction towards improving the standard of living of many people. ${ }^{2}$ One of the special characteristics and services found in the banking system is the fund transfer service using ATMs or credit cards and widely the existence of these uses is very large in our daily lives. The usage of ATMs in sending and / or transferring funds in the form of money has been known since 1967 in America with the name "cash dispenser "or" money machine ". This is so that someone can take money at the end of the week when the bank is closed, both day and night ${ }^{3}$

While in Indonesia the first use of an Automatic Teller Machine (ATM) in 1987 by Bank Niaga, according to Soetanto Hadinoto, the ATM was first developed because of the emergence of alternative transaction needs other than at bank branch offices, but customers were hesitant to use it, because it was not easy to generate trust customers at an ATM as a bank representative in helping him transact. Not to mention the use of the ATM machine itself, "Safe or not? can come out exactly the amount requested? How if money reduced from account without being asked? "Many parties have not yet looked at the reliability of this machine, some even scoffed. After Bank Niaga, Bank BCA provided an ATM in 1988, followed by other banks, when it became accustomed to using an ATM about 10 years later. ${ }^{4}$

However, along with its rapid development with the advantages and conveniences of the Electronic Found Transfer System (EFTs), especially ATMs, the facility certainly also has shortcomings or negative impacts that need attention that can also reduce the advantages of electronic services in banking, negative impacts include :

1. Debiting is not desired by the owner

2. Damage to the machine so it cannot take money

3. Transfer errors made through an ATM

\section{Crimes by third parties}

One of the modes of crime by third parties that often happens lately is Skimming, Skimming is a crime through an ATM that utilizes the negligence of customers because it is done by stealing ATM card PINs as the entrance to transactions. This technique is done by using a tool that is attached to the ATM machine slot (where the ATM card is inserted) with a device known as a skimmer. The mode of operation is to clone data from the magnetic stripe contained on the customer's ATM card. ${ }^{5}$

Crimes by third parties with this skimming mode are quite often in Indonesia, from year to year there are cases of skimming mode against bank customers, and this can reduce public trust in banking institutions. In addition, the Government through the Act has actually provided protection to customers as consumers in banking institutions, this can be seen from article 4 of Law No. 8 of 1999 concerning Consumer Protection that banks must provide security and safety to customer funds as users bank services

\footnotetext{
${ }^{2}$ Muhamad Djumhana, Banking Law in Indonesia, Citra Aditya Bakti, Bandung, 2000, Page 131

${ }^{3}$ J. milnes Holden, The Law and Practice of Banking Colume I, Banker and Customer, Pitman, 1980, Page 319

${ }^{4} \mathrm{https} / / /$ historia.id/politik/articles/mesin-atm-pertama-di-indonesia-PRgBg

${ }^{5}$ https://www.msn.com/id-id/berita/teknologidansains/waspada-6-cara-kuras-mesin-atm-senyap-dan-makin-gila/ar-AAAefIl
} 
that have entrusted their money to be managed by the bank, as also referred to in article $37 \mathrm{~B}$ number 1 Law No.10/1998 concerning Banking that each bank is required to guarantee public funds deposited in the bank concerned. So if there is a crime case by a third party with skimming mode as an example of the case above, the bank must also be willing to listen to the opinions and complaints of the customer as in paragraph 4 and also get protection and settlement of the crime by the third party in a manner true and honest, and also entitled to get compensation and compensation for the amount of money stolen by a third party if it is caused by a weak system of the bank so that third parties can steal customer funds.

Weaknesses and crimes by third parties in the banking sector are detrimental to customers and also the banks are inevitable in the era of increasingly sophisticated technology today, thus the legal regulations should also be updated to be able to continue to provide legal protection to customers as consumers In banking institutions, given the legal relationship between the customer and the bank based on a standard contract which is of course more profitable for the bank, for this reason the author would like to be interested in conducting research with the title "Juridical Analysis of Protection of Bank Clients From the Act of Skimming Viewed From the Law Consumer protection".

\section{Research Method}

The research method used in this study is a normative juridical, a research approach based on normative literature study and conducted through investigating law secondary data. ${ }^{6}$ To conduct this study, the researcher completes any materials required in studying and finishing this study by investigating the primary, secondary, and tertiary data. ${ }^{7}$ The techniques to collect the data are:

1. Literature study is conducted through collecting law materials relating to the study of materials, such as books of law whether in a form of written texts or soft-copy edition, such as e-books, journal articles, papers, government publication, and other sources provided in the internet and accessed via online. Besides, reading, studying, and noting some reviews of literature materials relating to the object of this study are conducted.

2. Study of interview was conducted to some related interviewees, such as the Head of National Land Agency of West Sumatera Province and Conveyance.

The method of data analysis used in this study is qualitative descriptive. Qualitative approach in this study is a procedure to produce descriptive data as revealed by the respondents orally and behaviorally. Then, the objects investigated and studied in this study is the whole research ${ }^{8}$.

\section{Research Findings and Discussion}

Forms of Legal Protection Against Bank Customers From Skimming Acts Reviewed From the Consumer Protection Law.

The definition of consumer protection is contained in Article 1 number 1 of Law No. 8 of 1999 concerning Consumer Protection, namely:

"Consumer protection is any effort that guarantees legal certainty to provide protection to consumers"

\footnotetext{
${ }^{6}$ Mamudji Sri, et al., Legal Research and Writing Methods, Faculty Publishing Board Law of the University of Indonesia, Jakarta, 2005,Page 4-5

${ }^{7}$ Adi Rianto, Social and Legal Research Methodology, Granite, Jakarta, 2004, page 31

${ }^{8}$ Soerjono Soekanto, Introduction to Legal Research, UI Press, Jakarta, 2006, Page 32
} 
The sentence which states "all efforts that guarantee legal certainty", are expected as a stronghold to negate arbitrary actions that harm business actors only in the interest of consumer protection, including in the form of legal protection ${ }^{9}$

According to Article 19 paragraph (1) and (3) of the Consumer Protection Law, consumers who feel disadvantaged can directly demand compensation from producers and producers must provide a response and / or settlement within 7 days after the transaction takes place. In addition, the settlement of consumer disputes also does not rule out the possibility of a peaceful settlement by the disputing parties, which means that it is settled outside the court. ${ }^{10}$

From the description above regarding the rights of consumers who can take the court or outside the court to settle the dispute is a form of legal protection given by the Act to customers as consumers as referred to in article 4 paragraph (5) of the Consumer Protection Law in which customers as consumers are entitled to get advocacy, protection, and efforts to resolve consumer protection disputes appropriately.

Legal protection against customers can be done in 2 (two) ways, namely:

a. Indirect protection, i.e. legal protection provided to customers against all risk of loss that may arise as a result of a bank's policy or business activities. Indirect protection provided to customers is in the form of providing information about possible risks of loss to customers, which is intended to make access to information about business activities and bank conditions more open and at the same time guarantee transparency in the banking world. Then the existence of bank secrecy, which is intended so that public trust is born if from the bank there is a guarantee that the bank's knowledge about customer deposits and financial condition will not be misused.

b. Direct protection, i.e. Direct protection for customers against possible risk of losses arising from business activities carried out by banks. Direct protection is in the form of the Consumer Protection Law for customers as consumers of financial services that provide legal certainty and protection for the rights of customers as consumers, and the establishment of a Deposit Insurance Corporation and requires each bank to guarantee public funds held in the bank concerned. ${ }^{11}$

Specifically in terms of providing legal protection to bank customers as consumers of financial services, the Financial Services Authority also has the duty to provide legal protection to consumers of financial service institutions. Regarding the Card Skimming case that caused losses for bank customers, the Financial Services Authority Law regulates consumer and community protection by taking preventative measures for consumers and the public, which include:

a. Providing information and education to the public on the characteristics of the financial services sector, services, and products;.

b. Ask for financial service institutions to stop their activities if the activity has the potential to harm the community; and

c. Other actions deemed necessary in accordance with statutory provisions in the financial services sector.

\footnotetext{
${ }^{9}$ Ahmadi Miru and Sutarman Yodo, Consumer Protection Law, Jakarta :, PT. Raja Grafindo Persada, 2004, Page 1

10 Janus Sidabalok, Consumer Protection Law in Indonesia „, Bandung: PT.Citra Aditya Bakti, 2006, Page 130-131

${ }^{11}$ Hermansyah, Revised Edition; Indonesian Banking Law, Jakarta, Kencana, 2009, Page 154
} 
In addition to efforts to prevent violations of the provisions in the Financial Services Authority Act, there are several instruments for the service of consumer complaints regarding violations committed by business actors, which include:

a. Preparing adequate tools for consumer complaints services that have been disadvantaged by actors in financial service institutions;

b. Create a complaint mechanism for consumers who have been disadvantaged by actors in financial service institutions; and

c. Facilitating the settlement of complaints of consumers who have been harmed by actors in financial services institutions in accordance with laws and regulations in the financial services sector.

Provision of Compensation for Bank Customers Affected by Skimming Acts Reviewed from the Consumer Protection Law

According to Muhamad Djumhana regarding bank obligations, with the guarantee of confidentiality of all public data in relation to the bank, the public trusted the bank. Furthermore, they will entrust their money to the bank or take advantage of bank services. Public trust is exist if there is a guarantee from the bank that the bank's knowledge about customers' savings and financial condition will not be misused. Thus if something happens to what the customer has entrusted to the bank and the customer experiences a loss, then the bank has the obligation to take responsibility and resolve it.

As a form of responsibility of the bank for customers who experience losses, of course, banks must provide compensation to bank customers who are disadvantaged due to this skimming. The responsibility of banks to provide compensation can be based on the existence of defaults that can also be against unlawful acts, but sometimes consumers are often hampered by restrictions or exemption from the seller's responsibility, as contained in standard unilateral agreements between the bank and the customer.

Regarding compensation, here are some obligations for business actors:

a. In good faith in carrying out its business activities;

b. Provide true, clear and honest information about the conditions and guarantees of goods and / or services and provide an explanation of the use, repair and maintenance;

d. Treat or serve consumers properly and honestly and not discriminatory;

e. Guarantee the quality of goods and / or services produced and / or traded based on the provisions of the applicable quality standards of goods and / or services;

f. Give consumers the opportunity to test, and / or try certain goods and / or services and provide guarantees and / or guarantees for goods made and / or traded;

g. Provide compensation, compensation and / or compensation for losses resulting from the use, use and utilization of traded goods and / or services;

h. Provide compensation, compensation and / or replacement if the goods and / or services received or used are not in accordance with the agreement

From the above article, it can be seen clearly about the compensation obligation that must be given by the bank if there is no other agreement in the previous standard contract.

For procedures for compensating customers who suffer losses, which is 14 (fourteen) working days after the customer makes a complaint to the bank that holds the customer's funds that have suffered losses due to card skimming mode. Because if the customer does not report, the bank also will not know of the existence of theft through the card skimming mode. ${ }^{12}$

\footnotetext{
${ }^{12}$ Interview with Mr. Hendri as staff in Branch Office of Bank Mandiri Pelalawan at 18 Juli 2019
} 
The Bank can indeed find out if there is an improper transaction in one of the accounts that is reasonably suspected of having stolen funds, but the bank only notifies by sending a warning text to the customer whose account balance is suspected to have been carried out by suspicious transaction. If the customer feels that there is a suspicious transaction after being warned by the bank, the customer is encouraged to contact the bank's call center where the customer opens an account or comes to the branch office. After the customer reports on the losses he has experienced after a maximum of 14 working days, only then will the bank reconcile.

For the loss suffered by the customer, the loss amount of money from the customer's account, then an investigation process is carried out, whether there is indeed a crime by a third party or there is an element of ommision from the customer's client. If there is indeed no element of ommision, the Bank will reimburse the customer money $100 \%$.

\section{Conclusion}

The form of legal protection for bank customers from acts of skimming reviewed from the consumer protection law that is indirect protection, and direct protection. and regarding compensation As mentioned in article 7 letter $\mathrm{g}$ of Consumer Protection Law that banks are obliged to provide compensation, compensation and / or compensation for losses resulting from the use, use and utilization of traded goods and / or services; namely compensation for a sum of money belonging to a customer that was previously lost due to no skimming which was proven without ad element ommision from customer.

\section{Suggestion}

in order to continue to provide legal protection to customers and maintain public confidence in financial institutions in the era of technology that is increasingly sophisticated, the legal regulations regarding banking and consumer protection must be kept up to date with the times and technology. Customers must alway to be aware and keep transactions safe.

\section{References \\ Books}

Djumhana, Muhamad, Banking Law in Indonesia, Citra Aditya Bakti, Bandung, 2000.

Holden, J. Milnes, The Law and Practice of Banking Colume I, Banker and Customer, Pitman, 1980.

Hermansyah, Revised Edition; Indonesian Banking Law, Jakarta, Kencana, 2009.

Mamudji Sri, et al., Legal Research and Writing Methods, Faculty Publishing Board.

Law of the University of Indonesia, Jakarta, 2005.

Miru, Ahmadi and Sutarman Yodo, Consumer Protection Law, Jakarta :, PT. Raja Grafindo Persada, 2004.

Rianto, Adi, Social and Legal Research Methodology, Granite, Jakarta, 2004. 
Sembiring, Sentosa, Association of Banking and Deposit Insurance Corporation, Bandung, Nuansa Aulia, 2005.

Sidabalok, Janus, Consumer Protection Law in Indonesia ,, Bandung: PT.Citra Aditya Bakti, 2006.

Soekanto, Soerjono, Introduction to Legal Research, UI Press, Jakarta, 2006.

\section{Legislation}

Law No. 8 of 1999 concerning Consumer Protection

Financial Services Authority Law

\section{Interview}

Interview with Mr. Hendri as staff in Branch Office of Bank Mandiri Pelalawan at July18, 2019

Website

https://historia.id/politik/articles/mesin-atm-pertama-di-indonesia-PRgBg

www.msn.com/id-id/berita/teknologidansains/waspada-6-cara-kuras-mesin-atm-senyap-dan-makingila/ar-AAAefIl

\section{Copyrights}

Copyright for this article is retained by the author(s), with first publication rights granted to the journal. This is an open-access article distributed under the terms and conditions of the Creative Commons Attribution license (http://creativecommons.org/licenses/by/4.0/). 